Corresponding author: sbpierce@uw.edu

(C) 2020 Kamal et al. This article is distributed under the terms of the Creative Commons Attribution-NonCommercial License, which permits reuse and redistribution, except for commercial purposes, provided that the original author and source are credited.

Ontology terms: anal atresia; aplasia/hypoplasia involving bones of the upper limbs; hand polydactyly; microcephaly; small for gestational age

Published by Cold Spring Harbor Laboratory Press

doi:10.1101/mcs.a005652

\section{Helicase-inactivating BRIP1 mutation yields Fanconi anemia with microcephaly and other congenital abnormalities}

\author{
Lara Kamal, ${ }^{1,2,7}$ Sarah B. Pierce, ${ }^{3,7}$ Christina Canavati, ${ }^{2}$ Amal Abu Rayyan, ${ }^{2}$ \\ Tamara Jaraysa, ${ }^{2}$ Orit Lobel, ${ }^{4}$ Suhair Lolas, ${ }^{2}$ Barbara M. Norquist, ${ }^{5}$ Grace Rabie ${ }^{2}$ \\ Fouad Zahdeh, ${ }^{2}$ Ephrat Levy-Lahad, ${ }^{4,6}$ Mary-Claire King, ${ }^{3}$ and Moien N. Kanaan ${ }^{1,2}$

\begin{abstract}
${ }^{1}$ Molecular Genetics Laboratory, Istishari Arab Hospital, Ramallah, Palestine; ${ }^{2}$ Hereditary Research Laboratory and Department of Biology, Bethlehem University, Bethlehem, Palestine; ${ }^{3}$ Departments of Medicine and Genome Sciences, University of Washington, Seattle, Washington 98195, USA; ${ }^{4}$ Medical Genetics Institute, Shaare Zedek Medical Center, Jerusalem 9103102, Israel; ${ }^{5}$ Division of Gynecologic Oncology, Department of Obstetrics and Gynecology, University of Washington, Seattle, Washington 98195, USA; ${ }^{6}$ Faculty of Medicine, Hebrew University of Jerusalem, Jerusalem 9112001, Israel
\end{abstract}

\begin{abstract}
Fanconi anemia is a genetically and phenotypically heterogeneous disorder characterized by congenital anomalies, bone marrow failure, cancer, and sensitivity of chromosomes to DNA cross-linking agents. One of the 22 genes responsible for Fanconi anemia is $B R I P 1$, in which biallelic truncating mutations lead to Fanconi anemia group $\mathrm{J}$ and monoallelic truncating mutations predispose to certain cancers. However, of the more than 1000 reported missense mutations in $B R I P 1$, very few have been functionally characterized. We evaluated the functional consequence of BRIP1 p.R848H (c.2543G > A), which was homozygous in two cousins with low birth weight, microcephaly, upper limb abnormalities, and imperforate anus and for whom chromosome breakage analysis of patient cells revealed increased mitomycin $\mathrm{C}$ sensitivity. BRIP1 p.R848H alters a highly conserved residue in the catalytic DNA helicase domain. We show that BRIP1 p.R848H leads to a defect in helicase activity. Heterozygosity at this missense has been reported in multiple cancer patients but, in the absence of functional studies, classified as of unknown significance. Our results support that this mutation is pathogenic for Fanconi anemia in homozygotes and for increased cancer susceptibility in heterozygous carriers.
\end{abstract}

[Supplemental material is available for this article.]

\section{INTRODUCTION}

Fanconi anemia is a genetically heterogeneous multisystemic disorder characterized by congenital anomalies, progressive bone marrow failure, cancer susceptibility, and cellular hypersensitivity to DNA cross-linking agents. At least 22 genes harbor mutations causing Fanconi anemia phenotypes (Mamrak et al. 2017; Niraj et al. 2019). Genes responsible for Fanconi anemia encode proteins in the BRCA/Fanconi DNA damage response pathway. Different protein complexes in the pathway collaborate in DNA damage repair, especially the removal

\footnotetext{
${ }^{7}$ These authors contributed equally to this work.
} 
and resolution of DNA interstrand cross-links to protect DNA replication fork stability (Kottemann and Smogorzewska 2013; Niraj et al. 2019). Proteins in the upstream core complex participate in DNA damage detection and signaling, culminating in the monoubiquitylation of the FANCD2/FANCl complex and its recruitment to interstrand cross-links (Niraj et al. 2019). Interstrand cross-links are then excised and bypassed in a process that generates double-stranded breaks. Resolution of the double-stranded breaks requires homologous recombination orchestrated by the downstream Fanconi anemia proteins, which include BRCA2 (FANCD1), BRIP1 (FANCJ), PALB2 (FANCN), RAD51C (FANCO), and BRCA1 (FANCS). Biallelic mutations in genes encoding proteins involved in homologous recombination cause Fanconi anemia and monoallelic mutations in these genes predispose to breast, ovarian, and other cancers (Niraj et al. 2019).

Because of the diversity of symptoms that can overlap with other genetic disorders, Fanconi anemia can be challenging to diagnose. Although bone marrow failure and cancer are hallmarks of Fanconi anemia, they may not develop until adulthood and some patients never develop these complications (Alter 2014). If Fanconi anemia is clinically diagnosed, the large number of causative genes and limited genotype-phenotype correlation make it difficult to predict which gene is responsible. We present here the identification of a BRIP1 variant and diagnosis of Fanconi anemia in a consanguineous family with two affected cousins presenting with multiple congenital abnormalities.

\section{RESULTS}

\section{Clinical Presentation}

We evaluated a 5 -yr-old female for a history of microcephaly and congenital malformations (HO3; Fig. 1A). She was the child of consanguineous parents of Palestinian ancestry. She presented at birth with low weight $(1.5 \mathrm{~kg})$, microcephaly, bilateral upper limb malformation, including four fingers and clenched hands, and imperforate anus. At age $5.5 \mathrm{yr}$ she is of normal height, although with poor weight gain, and can speak, walk, and run and attends preschool. Macrocytosis present soon after birth resolved by $5 \mathrm{mo}$; other complete blood count (CBC) values were near or within normal ranges (Supplemental Table 1). A brain computed tomography (CT) scan at age 5 mo and chromosomal microarray at age 2.5 mo were normal. Her brother, parents, and grandparents have none of the above manifestations.

A male cousin (HO7) of the proband presented with low birth weight, microcephaly, polydactyly, imperforate anus, and malformation of the gastrointestinal (Gl) tract. At age $22 \mathrm{yr}$ he has finished school and works with his father. He is reportedly healthy with normal blood counts. He had three deceased siblings with similar phenotypes. A sister, born with a small head, imperforate anus, and intestinal torsion, died at age $18 \mathrm{yr}$; the cause of death was reported as red blood cell hemolysis and septicemia. A brother, born with kidney problems and imperforate anus, died at $1 \mathrm{yr}$ of age. A second brother, born with imperforate anus, died at $10 \mathrm{~d}$ of age. His parents and grandparents have none of the above manifestations. The two cousins are related to each other through both parents. A great grandfather died of a hematological cancer; there is no other known history of cancer in the family.

\section{Gene Discovery}

Genomic DNA samples from the two affected cousins were evaluated by whole-exome sequencing (Table 1). Given the consanguinity of the family, data was filtered for shared homozygous rare variants predicted by in silico tools to be damaging. Three variants met these criteria: BRIP1 c.2543G > A, p.R848H (NM_032043.2) at Chr 17:59770823C > T, with one gnomAD entry; ENO4 c.1589A > T, p.D530V (NM_001242699.1) at Chr 10:118638853A > T, 
A

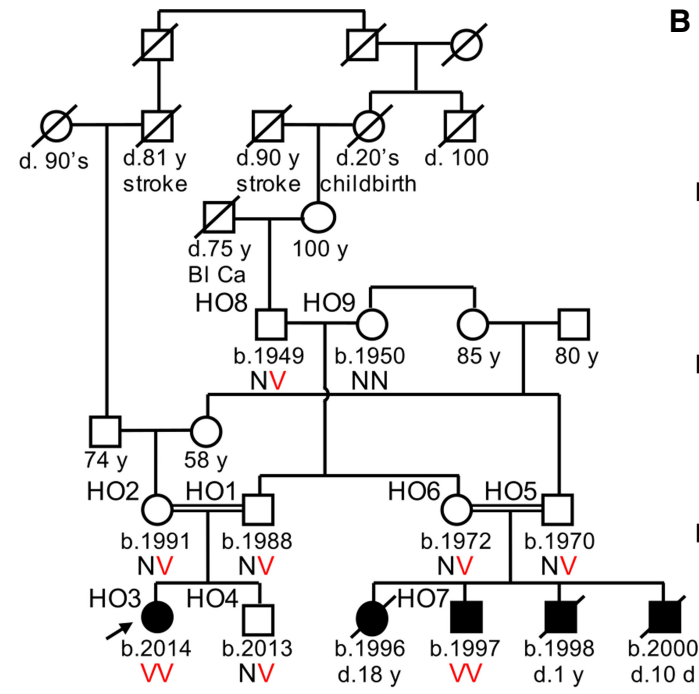

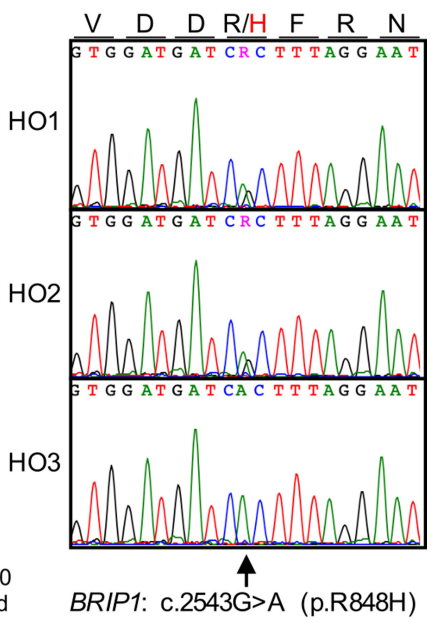

C

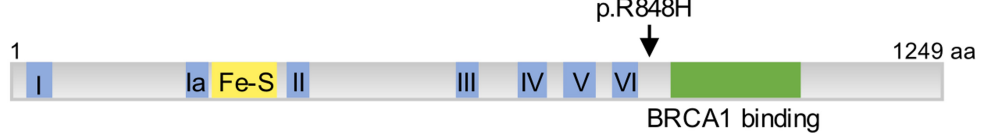

D

Figure 1. Identification of BRIP1 p.R848H in a family with microcephaly and congenital abnormalities. (A) Homozygosity for BRIP1 p.R848H cosegregates with microcephaly and congenital abnormalities in Palestinian family HO. Pedigree indicates affected individuals by filled symbols, unaffected individuals by open symbols, the proband by an arrow, and deceased individuals by slashes. Birth year, age, age at death, and cause of death are indicated below symbols. (BI Ca) Blood cancer. Genotypes for BRIP1 p.R848H are N for the reference allele and V for the mutant allele. (B) Sanger sequence traces indicate that BRIP1 c.2543G >A (p.R848H) is homozygous in the proband $\mathrm{HO} 3$ and heterozygous in her unaffected parents $\mathrm{HO} 1$ and HO2. (C) The domain architecture of BRIP1 includes an amino-terminal helicase domain (blue), with conserved helicase motifs (roman numerals), and iron-sulfur domain (yellow), and a carboxy-terminal BRCA1 binding domain (green). (D) Protein sequence alignment of BRIP1 orthologs and other human DEAH family helicases. The altered residue p.R848 is indicated in red and the core conserved residues of helicase motif VI by a line above.

with 34 gnomAD entries; and MED13 c.563T>C, p.L188P (NM_005121.2) at Chr 17:60112877A $>G$, with 93 gnomAD entries. The variants in ENO4, encoding an enolase, and MED13, encoding a component of the mediator complex, were considered unlikely to explain the phenotype and were not investigated further. Damaging variants in BRIP1, encoding a DNA helicase, are known to cause Fanconi anemia, which can include the features present in the affected cousins (Levitus et al. 2005; Levran et al. 2005; Litman et al. 2005; 


\begin{tabular}{lcc}
\hline Table 1. Exome sequencing metrics & & HO7 \\
\hline & HO3 & 34 \\
Average coverage, $x$ & 67 & 82 \\
$\%$ of targeted bases covered at $\geq 8 \times$ & 81 & 71 \\
$\%$ of target bases covered at $\geq 20 \times$ & 67 & \\
\hline
\end{tabular}

Fiesco-Roa et al. 2019). Sanger sequencing of peripheral blood-derived genomic DNA confirmed BRIP1 c.2543G > A, p.R848H to be homozygous in the affected cousins with no indication of somatic mosaicism (Table 2; Fig. 1A,B; Supplemental Fig. S1). BRIP1 c.2543G > A was confirmed to be heterozygous in each parent of the affected cousins and heterozygous or not present in all other unaffected family members evaluated. Female relatives ( $\mathrm{HO} 2$ and HO6) known to be heterozygous for BRIP1 c. $2543 \mathrm{G}>\mathrm{A}$ are currently ages 29 and 48. BRIP1 c. $2543 \mathrm{G}>\mathrm{A}$ was not present among exomes from approximately 1200 individuals (approximately 2400 alleles) in our in-house Palestinian databases. Nor does BRIP1 c.2543G > A appear among approximately 10,000 cancer-free women ( 20,000 alleles) older than age $70 \mathrm{yr}$ (https://whi.color.com).

BRIP1 (FANCJ) encodes a member of the DEAH family of ATP-dependent DNA helicases involved in interstrand cross-link repair. BRIP1 contains an amino-terminal helicase catalytic domain and a carboxy-terminal domain that includes a BRCA1 binding domain (Fig. 1C; Cantor et al. 2001, 2004). R848H affects a residue located at the carboxy-terminal end of the catalytic domain and is predicted to be damaging by PolyPhen-2 (score $=1.00)$ and $\mathrm{SIFT}(P=0.00)$. Arginine at residue 848 is conserved in all sequenced species and in other members of the DEAH helicase family (Fig. 1D).

\section{Chromosome Breakage Analysis}

The identification of a homozygous BRIP1 mutation suggested the possibility of Fanconi anemia. Consistent with a diagnosis of Fanconi anemia, peripheral blood lymphocytes from the proband $\mathrm{HO} 3$ showed increased chromosomal breakage after exposure to increasing concentrations of mitomycin $\mathrm{C}(\mathrm{MMC})$, compared to peripheral blood lymphocytes from her unaffected brother $\mathrm{HO} 4$ (Fig. 2). Proportions of cells with at least one radial chromosome after treatment with $150 \mathrm{nM} \mathrm{MMC}$ were 24 of 30 cells from the proband and 0 of 30 cells from her unaffected brother, Fisher (two-tailed) $P=3.29 \times 10^{-11}$. Proportions of cells with at least one acentric chromosome after treatment with $150 \mathrm{nM}$ MMC were seven of 30 cells from the proband and 0 of 30 cells from the unaffected brother, Fisher (two-tailed) $P=0.011$.

\section{Helicase Activity}

BRIP1 is known to unwind double-stranded DNA in the $5^{\prime}$-to-3' direction (Cantor et al. 2004). To determine whether the mutation identified in our patients alters this activity, we evaluated BRIP1 activity in vitro, using recombinant enzyme and a forked duplex substrate in which a

\begin{tabular}{|c|c|c|c|c|c|c|c|c|c|}
\hline Gene & $\begin{array}{l}\text { Chromo- } \\
\text { some }\end{array}$ & $\begin{array}{l}\text { HGVS DNA } \\
\text { reference }\end{array}$ & $\begin{array}{l}\text { HGVS } \\
\text { protein } \\
\text { reference }\end{array}$ & $\begin{array}{l}\text { Variant } \\
\text { type }\end{array}$ & $\begin{array}{c}\text { Predicted } \\
\text { effect }\end{array}$ & $\begin{array}{l}\text { dbSNP/ } \\
\text { dbVar ID }\end{array}$ & Genotype & ClinVar ID & $\begin{array}{l}\text { gnomAD } \\
\text { allele } \\
\text { frequency }\end{array}$ \\
\hline BRIP1 & $\begin{array}{l}\text { Chr17: } \\
\text { 59770823C > T } \\
\text { (hg19) }\end{array}$ & $\begin{array}{c}\text { NM_032043.2: } \\
\text { c.2543G > A }\end{array}$ & p.Arg848His & $\begin{array}{l}\text { Sub- } \\
\text { stitution }\end{array}$ & Missense & rs374334794 & Homozygous & SCV001429629 & 0.0000319 \\
\hline
\end{tabular}



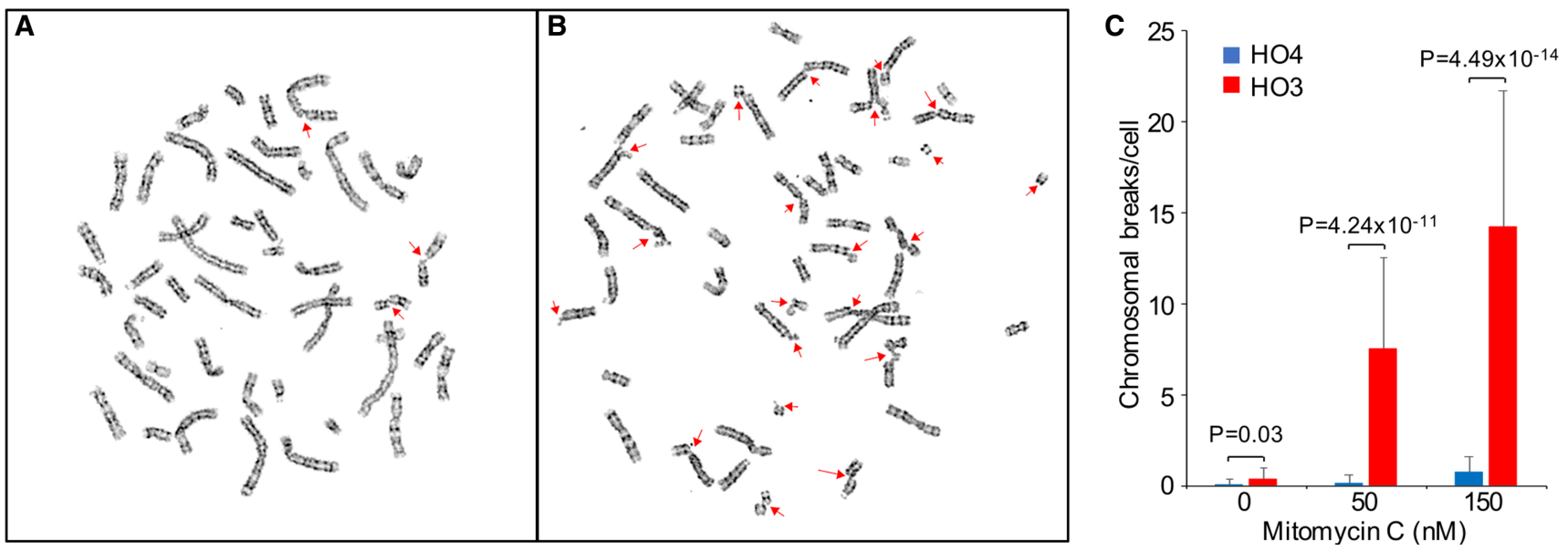

Figure 2. Increased chromosome breakage in family $\mathrm{HO}$ proband is diagnostic for Fanconi anemia. $(A, B)$ Representative metaphase spreads of peripheral blood lymphocytes from unaffected sibling $\mathrm{HO} 4(A)$ and affected proband $\mathrm{HO} 3(B)$ treated with $150 \mathrm{nM}$ mitomycin C. Red arrows indicate chromosomal breaks. (C) Number of breaks per cell after treatment with indicated mitomycin $C$ concentration. Values represent mean \pm SD of 30 cells per condition. $P$-values were determined by two-tailed $t$-test.

DNA duplex is flanked by single-stranded noncomplementary arms (Cantor et al. 2004; Gupta et al. 2005). Recombinant FLAG-tagged nonmutant and mutant BRIP1 was transiently expressed in HEK293T cells and isolated by immunoprecipitation. Increasing amounts of nonmutant BRIP1 exhibited increasing unwinding of a 26-bp forked duplex substrate, as indicated by the appearance of a band corresponding to the labeled single-stranded portion of the substrate (Fig. 3A). As a negative control, BRIP1 p.P47A, a variant known to lack catalytic activity (Cantor et al. 2004), exhibited no unwinding. BRIP1 p.R848H also showed no unwinding of the substrate, indicating that the helicase activity of this variant is compromised (Fig. 3A,C). The presence of all proteins was confirmed by western blot (Fig. 3B).

\section{DISCUSSION}

The limb, Gl, kidney, and growth abnormalities seen in this family have all been described in patients with Fanconi anemia group J (Shimamura and Alter 2010; Fiesco-Roa et al. 2019; Niraj et al. 2019). This constellation of congenital abnormalities in combination with cellular hypersensitivity to DNA cross-linking support a diagnosis of Fanconi anemia. The known role for BRIP1 mutations in Fanconi anemia, segregation with the phenotype in the family, and compromised helicase activity support our conclusion that BRIP1 p.R848H is the causal allele for the phenotype of this family. BRIP1 p.R848H has been reported in another patient with clinically diagnosed Fanconi anemia but functional significance of the mutation was not established (Steinberg-Shemer et al. 2019). BRIP1 p.R848H has been reported from six different sources on ClinVar and in breast and prostate cancer studies (Kim et al. 2016; Momozawa et al. 2020), all designating the variant as of "uncertain significance." Here we confirm the association of BRIP1 p.R848H with Fanconi anemia and demonstrate that the mutation impairs BRIP1 protein function.

$B R I P 1$ variants causing Fanconi anemia include both protein-truncating and missense variants. Like $\mathrm{R} 848 \mathrm{H}$, all other BRIP1 missense mutations causing Fanconi anemia target residues in the helicase domain. In addition, all other missense variants that have been functionally evaluated show deficits in helicase activity (Wu et al. 2010; Guo et al. 2014, Bharti et al. 
COLD SPRING HARBOR Molecular Case Studies
Helicase-inactivating BRIP1 mutation

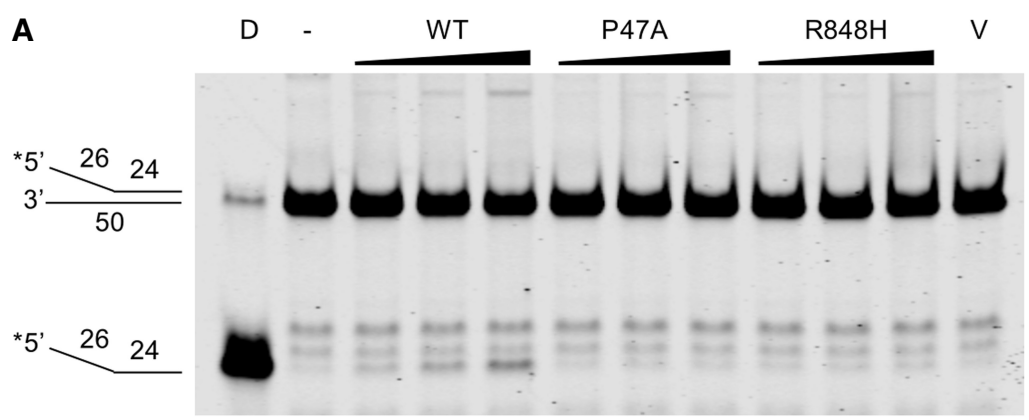

B

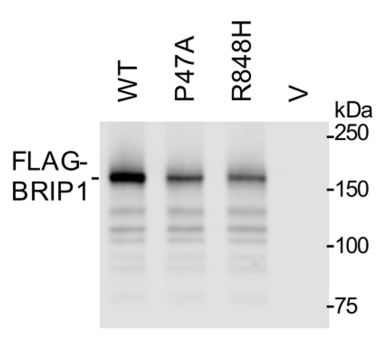

C

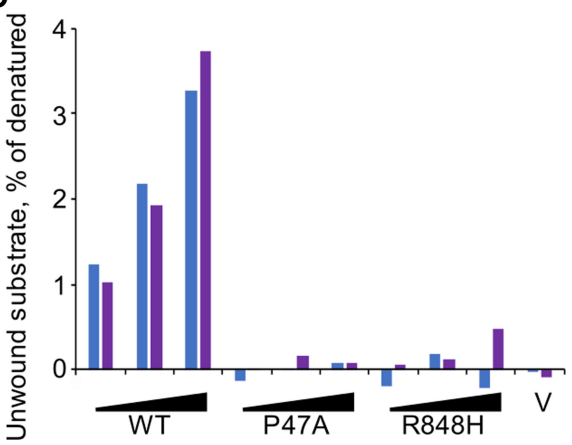

Figure 3. BRIP1 p.R848H causes a defect in helicase activity. (A) Unwinding of a partial-duplex 50-bp DNA substrate by nonmutant or mutant BRIP1 was assayed by measuring the amount of fluorescently labeled oligonucleotide unwound from the intact substrate. Construction of the partial-duplex DNA substrate is described in Methods. The sketch of the partial-duplex substrate indicates the position of the intact substrate, with its labeled $5^{\prime}$ end indicated by ${ }^{*}$. The sketch of the single-stranded substrate indicates the position of the substrate after it has been unwound. Lane $\Delta$ shows heat denatured substrate, revealing the position of the single-stranded substrate when completely unwound. Lane (-) indicates level of unwinding in the absence of BRIP1. Other lanes show effects of adding increasing amounts of immune precipitate from cells transfected with vectors encoding nonmutant BRIP1 (WT), a known helicase-defective mutant BRIP1 p.P47A, BRIP1 p.R848H, or empty vector (V). (B) Western blot of immune precipitates used for helicase assay in $A$. (C) Percent of substrate unwound versus concentrations of immune precipitate containing BRIP1, corrected for background in the absence of immune precipitate, from lane (-). For nonmutant protein, the slope of the regression of unwound substrate versus immune precipitate concentration is $r=0.986$ ( $95 \%$ confidence interval $[0.85,1.00]$ ), $P=0.0005$ (two-tailed); for BRIP1 p.P47A, $r=0.49[-0.55,0.93], P=0.32$; for BRIP1 p.R848H, $r=0.29[-0.68,0.89], P=0.56$. Measures based on two independent experiments at each condition.

2018). Patient-derived FA-J cells, which lack BRIP1, are sensitive to interstrand cross-linking agents (Litman et al. 2005). Cellular resistance to interstrand cross-linking can be restored by the reintroduction of BRIP1 (Peng et al. 2007). Restoration of resistance requires BRIP1 helicase activity but not BRIP1-BRCA1 interaction, demonstrating the importance of the helicase domain and suggesting an explanation for why missense mutations particularly targeting the helicase domain may be causal for Fanconi anemia.

Neither of the surviving affected individuals in our family have thus far been diagnosed with bone marrow failure. The similar congenital abnormalities in the three deceased siblings of $\mathrm{HO} 7$ suggest that they were also homozygous for BRIP1 p.R848H, but their hematological phenotypes are not known. Hematological abnormalities are a hallmark feature of Fanconi anemia but are not present in all patients. The cumulative incidence of bone marrow failure in Fanconi anemia generally is $50 \%$ by age 40 , with annual risk peaking by age $7 \mathrm{yr}$ (Alter 2014). Homozygosity or compound heterozygosity for BRIP1 truncating alleles was associated with bone marrow failure in early childhood in 12 of 14 cases, generally by the age of $6 \mathrm{yr}$ 
(Levitus et al. 2004, 2005; Levran et al. 2005; Ghazwani et al. 2016). All BRIP1 truncating alleles yield loss of the helicase domain and are likely to lead to loss of protein (Levitus et al. 2004; Levitus et al. 2005; Levran et al. 2005; Litman et al. 2005; Steinberg-Shemer et al. 2019). Missense alleles, which may retain at least partial protein expression and function (Levitus et al. 2005; Bharti et al. 2018; Moyer et al. 2020), may cause a less severe phenotype. A recent analysis of genotype-phenotype associations in Fanconi anemia found an increased frequency of congenital abnormalities in patients with null genotypes compared to those with hypomorphic genotypes, suggesting that phenotypic severity may be influenced by the type of mutation (Fiesco-Roa et al. 2019), although other studies have found conflicting results (Faivre et al. 2000; Castella et al. 2011; Steinberg-Shemer et al. 2019). Most reports of homozygous or compound heterozygous BRIP1 missense mutations have not included phenotypic details (Levitus et al. 2005; Chandrasekharappa et al. 2013; Steinberg-Shemer et al. 2019). Additional phenotypic information from individuals with BRIP1 missense genotypes will be needed to determine whether the class of BRIP1 mutation influences phenotype severity. Protection from bone marrow failure may result from hematopoietic somatic mosaicism caused by the correction of one mutant allele in a somatic reversion event (Shimamura and Alter 2010). Somatic mosaicism is ruled out in our patients by detection of only the BRIP1 c.2543G > A allele in peripheral blood.

Cancer risks for individuals with Fanconi anemia caused by biallelic BRIP1 mutations have not been documented. However, patients with biallelic mutations in certain other Fanconi anemia genes have cumulative risks of $20 \%$ for leukemia and $30 \%$ for solid tumors by age 40 (Alter 2014). Biallelic mutations in BRCA2/FANCD1 or BRCA1/FANCS are generally embryonic lethal; surviving patients have very high cancer risks and BRCA2/FANCD1 patients have extremely elevated rates of spontaneous and induced chromosome breakage (Gowen et al. 1996; Hakem et al. 1996; Ludwig et al. 1997; Hirsch et al. 2004; Alter et al. 2007; Myers et al. 2012; Domchek et al. 2013; Shaheen et al. 2014; Sawyer et al. 2015; Loizidou et al. 2016; Seo et al. 2018, Weinberg-Shukron et al. 2018). It is likely that the patients in our study who are homozygous for BRIP1 p.R848H will also be at increased risk for these malignancies and will benefit from ongoing surveillance.

Heterozygous BRIP1 loss-of-function mutations predispose to ovarian cancer (Rafnar et al. 2011; Ramus et al. 2015; Norquist et al. 2016; Weber-Lassalle et al. 2018), and current National Comprehensive Cancer Network guidelines indicate that risk-reducing salpingo-oophorectomy should be considered between the ages of 45-50 for women with these mutations (https://www.nccn.org/professionals/physician_gls/pdf/genetics_screening.pdf). These loss-of-function mutations include rare BRIP1 missense mutations that have been shown experimentally to have no or greatly reduced protective activity against DNA-damaging agents (Moyer et al. 2020). BRIP1 p.R848H, with defective helicase activity, may also increase the risk of ovarian cancer. Early studies also implicated BRIP1 as a breast cancer susceptibility gene (Seal et al. 2006; De Nicolo et al. 2008), although there has been conflicting evidence (Easton et al. 2016; Couch et al. 2017). A recent study suggests that BRIP1 may be associated specifically with triple-negative breast cancer (Shimelis et al. 2018). The family of this study is not informative for cancer risk among female carriers, because the female relatives known to be heterozygous for the missense are presently ages 29 and 48 .

Of more than 1000 different BRIP1 missense mutations reported in ClinVar, very few have been functionally evaluated. The clinical significance of the vast majority is listed as uncertain with respect to both cancer predisposition and Fanconi anemia group J. Six missense mutations previously identified in patients with Fanconi anemia (R251C, Q255H, A349P, H396D, W647C, R707C) have been shown to be deficient for helicase activity (Levitus et al. 2005; Levran et al. 2005; Wu et al. 2010; Chandrasekharappa et al. 2013; Guo et al. 2014; Bharti et al. 2018). BRIP1 p.P47A, originally identified in a breast cancer patient and used as a negative control in our study, is also helicase-deficient (Cantor et al. 2004). A recent study 
evaluated 18 additional BRIP1 missense mutations identified in ovarian and early-onset breast cancer patients for protein stability and effects on cell growth, cell cycle progression, and chromosome breakage in the presence of DNA damaging agents (Moyer et al. 2020). Thirteen of these mutations were null or depleted in one or more of these functions, whereas five had fully normal function. Our finding that BRIP1 p.R848H lacks helicase activity adds to the small but growing number of BRIP1 missense mutations with demonstrated functional impact.

The similar congenital abnormalities in the cousins in our study suggested a genetic disorder. Although their features are consistent with Fanconi anemia, the physical features of Fanconi anemia overlap with those of other multisystem genetic disorders. Fanconi anemia commonly presents with blood pancytopenia (Shimamura and Alter 2010), but CBC results for the proband were not significant enough to prompt further evaluation of bone marrow or chromosome breakage analysis. The phenotypic and genetic heterogeneity of Fanconi anemia can make it challenging to reach a clinical diagnosis and to predict the genetic cause. In this case, exome sequencing provided a genetic diagnosis that led to a clinical diagnosis of Fanconi anemia and the opportunity for surveillance appropriate to the ongoing risks for cancer and bone marrow abnormalities.

\section{METHODS}

\section{Exome Sequencing}

Genomic DNA was extracted from peripheral blood samples, quantified using Qubit v. 3 and quality checked by gel electrophoresis. Library preparation was carried out using TruSeq Capture Exome Kit (Illumina). This kit provides coverage of $45 \mathrm{Mb}$ of exonic content. After sequencing on NextSeq 500, data was uploaded onto our server and reads were aligned to the reference human genome (hg19) using BWA aligner. Prior to variant calling by GATK (Genome Analysis Toolkit), mapped reads (BAM format) went through preprocessing steps by removing PCR duplicates, realigning around indels, and recalibrating base quality. The final list of variants was annotated by ANNOVAR (http://annovar.openbioinformatics .org/) (Wang et al. 2010) using several databases of minor allele frequency such as gnomAD (https://gnomad.broadinstitute.org) and PopFreqMax as well as variant effect predictors such as SIFT (Sorting Intolerant From Tolerant; http://sift.bii.a-star.edu.sg), PolyPhen2 (http://genetics.bwh.harvard.edu/pph2/) and REVEL (loannidis et al. 2016). Variants with low coverage, which were synonymous or predicted benign (SIFT, PolyPhen-2, REVEL), or with frequency $>0.001$ on gnomAD, PopFreqMax, or in our Palestinian in-house database were excluded. Candidate variants were validated by Sanger sequencing and tested for cosegregation with the phenotype in additional family members. Primers used for validation of BRIP1 c.2543G > A were 5'-CCAGCTGAGATCTTACCAGA-3' and 5'-CAACATTTTG GATGCAAGTT-3'.

\section{Chromosome Breakage Analysis}

Chromosome breakage analysis was performed essentially as previously described (Tenenbaum-Rakover et al. 2015). Peripheral blood lymphocytes were cultured for $72 \mathrm{~h}$ with 0,150 , or $300 \mathrm{nM}$ mitomycin C. At least 30 metaphase spreads were evaluated by microscopy for chromosomal aberrations.

\section{BRIP1 Isolation by Immunoprecipitation}

Constructs in which nonmutant or mutant BRIP1 with a carboxy-terminal FLAG tag was expressed from the PCMV-3Tag-3 vector (Stratagene) were generated using the Gibson assembly method (Gibson et al. 2009). HEK293T cells in two 15-cm dishes were transfected 
with $60 \mu \mathrm{g}$ of DNA and $150 \mu \mathrm{L}$ of Lipofectamine 2000 (ThermoFisher) per dish, according to manufacturer's instructions, and protein was isolated essentially as described (Wu et al. 2010). Cells were lysed $48 \mathrm{~h}$ after transfection in buffer containing $10 \mathrm{mM}$ Tris- $\mathrm{HCl}, \mathrm{pH}$ $7.4,130 \mathrm{mM} \mathrm{NaCl}, 1 \%$ Triton $\mathrm{X}-100,10 \mathrm{mM}$ sodium fluoride, $1 \mathrm{mM}$ sodium orthovanadate and a protease inhibitor cocktail (ThermoFisher). BRIP1 was immunoprecipitated from clarified cell lysate with anti-DYKDDDDK magnetic agarose beads (ThermoFisher), using 7.6 $\mu \mathrm{L}$ bead slurry per $\mathrm{mg}$ protein. Immune precipitates were washed twice in $50 \mathrm{mM}$ Tris$\mathrm{HCl}, \mathrm{pH} 7.4,500 \mathrm{mM} \mathrm{NaCl}, 0.5 \%$ Nonidet P-40 and twice in $50 \mathrm{mM}$ Tris-HCl, pH 7.4, 150 $\mathrm{mM} \mathrm{NaCl}, 0.5 \%$ Nonidet P-40. Beads were stored as a $50 \%$ slurry in storage buffer $(25$ $\mathrm{mM}$ Tris- $\mathrm{HCl}, \mathrm{pH} 7.4,100 \mathrm{mM} \mathrm{NaCl}, 10 \%$ glycerol, 0.1\% Tween-20, $0.5 \mathrm{mM}$ TCEP (tris(2-carboxyethyl)phosphine)) in aliquots at $-80^{\circ} \mathrm{C}$.

\section{Helicase Assays}

DNA helicase assays were performed on BRIP1-containing immune precipitates (Moser et al. 2000; Kamath-Loeb et al. 2004), and activity was detected by the displacement of an oligonucleotide labeled with IRDye700 from a partial duplex substrate. Based on previously published substrates (Gupta et al. 2005; Rudolf et al. 2006), the forked substrate consisted of the labeled oligonucleotide X50 (5'-IRD700-GCTCGAGTCTAGACTGCAGTTGAGAGCTTGC TAGGACGGATCCCTCGAGG) and an unlabeled oligonucleotide (5'-CCTCGAGGGATC CGTCCTAGCAAGAGGATTTTTTTTTTTTTTTTTTTTTTTT) (IDT), annealed to form a 24-bp duplex flanked by 26-nt single-stranded DNA tails. Immune precipitates containing BRIP1 were diluted in storage buffer, and helicase activity was routinely assayed at dilutions of 1:128 to 1:32; activity was linear in this range. Helicase reactions $(20 \mu \mathrm{L})$ contained $40 \mathrm{mM}$ Tris- $\mathrm{HCl}$, $\mathrm{pH} 7.4,25 \mathrm{mM} \mathrm{KCl}, 5 \mathrm{mM} \mathrm{MgCl} 2,2 \%$ glycerol, $100 \mathrm{ng} / \mathrm{mL}$ bovine serum albumin, $2 \mathrm{mM}$ dithiothreitol, $2 \mathrm{mM}$ adenosine triphosphate, $0.5 \mathrm{nM}$ partial duplex DNA substrate, and BRIP1 immune precipitate (Cantor et al. 2004). Reactions were incubated for $30 \mathrm{~min}$ at $30^{\circ} \mathrm{C}$, with mixing, and stopped with a mixture of $2.2 \mu \mathrm{L} \mathrm{10 \times} \mathrm{loading} \mathrm{dye} \mathrm{(LI-COR} \mathrm{Biosciences)} \mathrm{and} 0.8$ $\mu \mathrm{L} 125 \mathrm{mM}$ unlabeled X50 oligonucleotide. Reaction products were resolved on 10\% polyacrylamide TBE gels (ThermoFisher), visualized on an Odyssey infrared imaging system (LICOR Biosciences), and quantified using Image Studio Lite (LI-COR Biosciences).

\section{Western Blots}

In parallel to each helicase assay, equivalent amounts of BRIP1 immune precipitate 1:32 dilutions were separated by SDS/PAGE, transferred to Immobilon-FL membrane (Millipore), and immunoblotted with mouse anti-FLAG M2 (Sigma-Aldrich, F1804, 1:1000). Proteins were detected with IRDye680RD-conjugated secondary antibody, followed by analysis with an Odyssey infrared imaging system (LI-COR Biosciences).

\section{ADDITIONAL INFORMATION}

\section{Data Deposition and Access}

Our patient consent does not permit us to make patient sequence data publicly available. The BRIP1 variant identified in this study was submitted to ClinVar (https://www.ncbi.nlm .nih.gov/clinvar/) and can be found under the accession number SCV001429629.

\section{Ethics Statement}

This study was approved by the institutional review boards of Bethlehem University and the University of Washington, Seattle. Written informed consent was provided by adults and by parents of minor children. 
Competing Interest Statement

The authors have declared no competing interest.

Received June 10, 2020; accepted in revised form August 11, 2020

\section{Acknowledgments}

We thank the family for their willingness to participate in this study.

\section{Author Contributions}

M.N.K., M.C.K., and E.L.L. designed the study. M.N.K. supervised data collection. L.K. obtained, analyzed, and interpreted data. S.B.P. designed and performed biochemical assays. C.C., A.A.R., T.J., S.L., and G.R. obtained data. O.L. performed chromosome breakage testing. F.Z. analyzed data. S.B.P. wrote the manuscript and prepared figures. M.N.K., M.C.K., E.L.L., and B.M.N. contributed to manuscript revisions.

\section{Funding}

This work was supported by the Ishtishari Arab Hospital and grants from the Breast Cancer Research Foundation (to E.L.L., M.C.K., and M.N.K.) and from the National Institutes of Health (NIH) (1R35CA197458 to M.C.K.).

\section{REFERENCES}

Alter BP. 2014. Fanconi anemia and the development of leukemia. Best Pract Res Clin Haematol 27: 214-221. doi:10.1016/j.beha.2014.10.002

Alter BP, Rosenberg PS, Brody LC. 2007. Clinical and molecular features associated with biallelic mutations in FANCD1/BRCA2. J Med Genet 44: 1-9. doi:10.1136/jmg.2006.043257

Bharti SK, Sommers JA, Awate S, Bellani MA, Khan I, Bradley L, King GA, Seol Y, Vidhyasagar V, Wu Y, et al. 2018. A minimal threshold of FANCJ helicase activity is required for its response to replication stress or double-strand break repair. Nucleic Acids Res 46: 6238-6256. doi:10.1093/nar/gky403

Cantor SB, Bell DW, Ganesan S, Kass EM, Drapkin R, Grossman S, Wahrer DC, Sgroi DC, Lane WS, Haber DA, et al. 2001. BACH1, a novel helicase-like protein, interacts directly with BRCA1 and contributes to its DNA repair function. Cell 105: 149-160. doi:10.1016/S0092-8674(01)00304-X

Cantor S, Drapkin R, Zhang F, Lin Y, Han J, Pamidi S, Livingston DM. 2004. The BRCA1-associated protein $\mathrm{BACH} 1$ is a DNA helicase targeted by clinically relevant inactivating mutations. Proc Natl Acad Sci 101: 2357-2362. doi:10.1073/pnas.0308717101

Castella M, Pujol R, Callén E, Trujillo JP, Casado JA, Gille H, Lach FP, Auerbach AD, Schindler D, Benítez J, et al. 2011. Origin, functional role, and clinical impact of Fanconi anemia FANCA mutations. Blood 117: 3759-3769. doi:10.1182/blood-2010-08-299917

Chandrasekharappa SC, Lach FP, Kimble DC, Kamat A, Teer JK, Donovan FX, Flynn E, Sen SK, Thongthip S, Sanborn E, et al. 2013. Massively parallel sequencing, aCGH, and RNA-Seq technologies provide a comprehensive molecular diagnosis of Fanconi anemia. Blood 121: e138-e148. doi:10.1182/blood-2012-12474585

Couch FJ, Shimelis H, Hu C, Hart SN, Polley EC, Na J, Hallberg E, Moore R, Thomas A, Lilyquist J, et al. 2017. Associations between cancer predisposition testing panel genes and breast cancer. JAMA Oncol 3: 11901196. doi:10.1001/jamaoncol.2017.0424

De Nicolo A, Tancredi M, Lombardi G, Flemma CC, Barbuti S, Di Cristofano C, Sobhian B, Bevilacqua G, Drapkin R, Caligo MA. 2008. A novel breast cancer-associated BRIP1 (FANCJ/BACH1) germ-line mutation impairs protein stability and function. Clin Cancer Res 14: 4672-4680. doi:10.1158/1078-0432.CCR-080087

Domchek SM, Tang J, Stopfer J, Lilli DR, Hamel N, Tischkowitz M, Monteiro AN, Messick TE, Powers J, Yonker A, et al. 2013. Biallelic deleterious BRCA1 mutations in a woman with early-onset ovarian cancer. Cancer Discov 3: 399-405. doi:10.1158/2159-8290.CD-12-0421

Easton DF, Lesueur F, Decker B, Michailidou K, Li J, Allen J, Luccarini C, Pooley KA, Shah M, Bolla MK, et al. 2016. No evidence that protein truncating variants in BRIP1 are associated with breast cancer risk: implications for gene panel testing. J Med Genet 53: 298-309. doi:10.1136/jmedgenet-2015-103529

Faivre L, Guardiola P, Lewis C, Dokal I, Ebell W, Zatterale A, Altay C, Poole J, Stones D, Kwee ML, et al. 2000. Association of complementation group and mutation type with clinical outcome in Fanconi anemia. Blood 96: 4064-4070.

Fiesco-Roa MO, Giri N, McReynolds LJ, Best AF, Alter BP. 2019. Genotype-phenotype associations in Fanconi anemia: a literature review. Blood Rev 37: 100589. doi:10.1016/j.blre.2019.100589 
Ghazwani Y, AlBalwi M, Al-Abdulkareem I, Al-Dress M, Alharbi T, Alsudairy R, Alomari A, Aljamaan K, Essa M, Al-Zahrani M, et al. 2016. Clinical characteristics and genetic subtypes of Fanconi anemia in Saudi patients. Cancer Genet 209: 171-176. doi:10.1016/j.cancergen.2016.02.003

Gibson DG, Young L, Chuang RY, Venter JC, Hutchison CA III, Smith HO. 2009. Enzymatic assembly of DNA molecules up to several hundred kilobases. Nat Methods 6: 343-345. doi:10.1038/ nmeth.1318

Gowen LC, Johnson BL, Latour AM, Sulik KK, Koller BH. 1996. Brca1 deficiency results in early embryonic lethality characterized by neuroepithelial abnormalities. Nat Genet 12: 191-194. doi:10.1038/ng0296191

Guo M, Vidhyasagar V, Ding H, Wu Y. 2014. Insight into the roles of helicase motif la by characterizing Fanconi anemia group J protein (FANCJ) patient mutations. J Biol Chem 289: 10551-10565. doi:10.1074/jbc M113.538892

Gupta R, Sharma S, Sommers JA, Jin Z, Cantor SB, Brosh RM Jr. 2005. Analysis of the DNA substrate specificity of the human BACH1 helicase associated with breast cancer. J Biol Chem 280: 25450-25460. doi:10.1074/ jbc.M501995200

Hakem R, de la Pompa JL, Sirard C, Mo R, Woo M, Hakem A, Wakeham A, Potter J, Reitmair A, Billia F, et al. 1996. The tumor suppressor gene Brca1 is required for embryonic cellular proliferation in the mouse. Cell 85: 1009-1023. doi:10.1016/S0092-8674(00)81302-1

Hirsch B, Shimamura A, Moreau L, Baldinger S, Hag-alshiekh M, Bostrom B, Sencer S, D'Andrea AD. 2004. Association of biallelic BRCA2/FANCD1 mutations with spontaneous chromosomal instability and solid tumors of childhood. Blood 103: 2554-2559. doi:10.1182/blood-2003-06-1970

loannidis NM, Rothstein JH, Pejaver V, Middha S, McDonnell SK, Baheti S, Musolf A, Li Q, Holzinger E, Karyadi $D$, et al. 2016. REVEL: an ensemble method for predicting the pathogenicity of rare missense variants. Am J Hum Genet 99: 877-885. doi:10.1016/j.ajhg.2016.08.016

Kamath-Loeb AS, Welcsh P, Waite M, Adman ET, Loeb LA. 2004. The enzymatic activities of the Werner syndrome protein are disabled by the amino acid polymorphism R834C. J Biol Chem 279: 55499-55505. doi:10.1074/jbc.M407128200

Kim H, Cho DY, Choi DH, Jung GH, Shin I, Park W, Huh SJ, Nam SJ, Lee JE, Gil WH, et al. 2016. Analysis of BRIP1 variants among Korean patients with BRCA1/2 mutation-negative high-risk breast cancer. Cancer Res Treat 48: 955-961. doi:10.4143/crt.2015.191

Kottemann MC, Smogorzewska A. 2013. Fanconi anaemia and the repair of Watson and Crick DNA crosslinks. Nature 493: 356-363. doi:10.1038/nature11863

Levitus M, Rooimans MA, Steltenpool J, Cool NF, Oostra AB, Mathew CG, Hoatlin ME, Waisfisz Q, Arwert F, de Winter JP, et al. 2004. Heterogeneity in Fanconi anemia: evidence for 2 new genetic subtypes. Blood 103: 2498-2503. doi:10.1182/blood-2003-08-2915

Levitus M, Waisfisz Q, Godthelp BC, de Vries Y, Hussain S, Wiegant WW, Elghalbzouri-Maghrani E, Steltenpool J, Rooimans MA, Pals G, et al. 2005. The DNA helicase BRIP1 is defective in Fanconi anemia complementation group J. Nat Genet 37: 934-935. doi:10.1038/ng1625

Levran O, Attwooll C, Henry RT, Milton KL, Neveling K, Rio P, Batish SD, Kalb R, Velleuer E, Barral S, et al. 2005. The BRCA1-interacting helicase BRIP1 is deficient in Fanconi anemia. Nat Genet 37: 931-933. doi:10 .1038/ng1624

Litman R, Peng M, Jin Z, Zhang F, Zhang J, Powell S, Andreassen PR, Cantor SB. 2005. BACH1 is critical for homologous recombination and appears to be the Fanconi anemia gene product FANCJ. Cancer Cell 8: 255-265. doi:10.1016/j.ccr.2005.08.004

Loizidou MA, Hadjisavvas A, Tanteles GA, Spanou-Aristidou E, Kyriacou K, Christophidou-Anastasiadou V. 2016. Fanconi anemia-D1 due to homozygosity for the BRCA2 gene Cypriot founder mutation: a case report. Oncol Lett 11: 471-473. doi:10.3892/ol.2015.3852

Ludwig T, Chapman DL, Papaioannou VE, Efstratiadis A. 1997. Targeted mutations of breast cancer susceptibility gene homologs in mice: lethal phenotypes of Brca1, Brca2, Brca1/Brca2, Brca1/p53, and Brca2/p53 nullizygous embryos. Genes Dev 11: 1226-1241. doi:10.1101/gad.11.10.1226

Mamrak NE, Shimamura A, Howlett NG. 2017. Recent discoveries in the molecular pathogenesis of the inherited bone marrow failure syndrome Fanconi anemia. Blood Rev 31: 93-99. doi:10.1016/j.blre.2016 .10 .002

Momozawa Y, Iwasaki Y, Hirata M, Liu X, Kamatani Y, Takahashi A, Sugano K, Yoshida T, Murakami Y, Matsuda K, et al. 2020. Germline pathogenic variants in 7636 Japanese patients with prostate cancer and 12366 controls. J Natl Cancer Inst 112: 369-376. doi:10.1093/jnci/djz124

Moser MJ, Kamath-Loeb AS, Jacob JE, Bennett SE, Oshima J, Monnat RJ Jr. 2000. WRN helicase expression in Werner syndrome cell lines. Nucleic Acids Res 28: 648-654. doi:10.1093/nar/28.2.648

Moyer CL, Ivanovich J, Gillespie JL, Doberstein R, Radke MR, Richardson ME, Kaufmann SH, Swisher EM, Goodfellow PJ. 2020. Rare BRIP1 missense alleles confer risk for ovarian and breast cancer. Cancer Res 80: 857-867. doi:10.1158/0008-5472.CAN-19-1991 
Myers K, Davies SM, Harris RE, Spunt SL, Smolarek T, Zimmerman S, McMasters R, Wagner L, Mueller R, Auerbach $A D$, et al. 2012. The clinical phenotype of children with Fanconi anemia caused by biallelic FANCD1/BRCA2 mutations. Pediatr Blood Cancer 58: 462-465. doi:10.1002/pbc.23168

Niraj J, Färkkilä A, D’Andrea AD. 2019. The Fanconi anemia pathway in cancer. Annu Rev Cancer Bio/ 3: 457478. doi:10.1146/annurev-cancerbio-030617-050422

Norquist BM, Harrell MI, Brady MF, Walsh T, Lee MK, Gulsuner S, Bernards SS, Casadei S, Yi Q, Burger RA, et al. 2016. Inherited mutations in women with ovarian carcinoma. JAMA Oncol 2: 482-490. doi:10 .1001/jamaoncol.2015.5495

Peng M, Litman R, Xie J, Sharma S, Brosh RM Jr, Cantor SB. 2007. The FANCJ/MutLa interaction is required for correction of the cross-link response in FA-J cells. EMBO J 26: 3238-3249. doi:10.1038/sj.emboj .7601754

Rafnar T, Gudbjartsson DF, Sulem P, Jonasdottir A, Sigurdsson A, Jonasdottir A, Besenbacher S, Lundin P, Stacey SN, Gudmundsson J, et al. 2011. Mutations in BRIP1 confer high risk of ovarian cancer. Nat Genet 43: 1104-1107. doi:10.1038/ng.955

Ramus SJ, Song H, Dicks E, Tyrer JP, Rosenthal AN, Intermaggio MP, Fraser L, Gentry-Maharaj A, Hayward J, Philpott S, et al. 2015. Germline mutations in the BRIP1, BARD1, PALB2, and NBN genes in women with ovarian cancer. J Natl Cancer Inst 107: djv214. doi:10.1093/jnci/djv214

Rudolf J, Makrantoni V, Ingledew WJ, Stark MJ, White MF. 2006. The DNA repair helicases XPD and Fanc have essential iron-sulfur domains. Mol Cell 23: 801-808. doi:10.1016/j.molcel.2006.07.019

Sawyer SL, Tian L, Kähkönen M, Schwartzentruber J, Kircher M; University of Washington Centre for Mendelian Genomics; FORGE Canada Consortium, Majewski J, Dyment DA, Innes AM, et al. 2015. Biallelic mutations in BRCA1 cause a new Fanconi anemia subtype. Cancer Discov 5: 135-142. doi:10.1158/2159-8290.CD14-1156

Seal S, Thompson D, Renwick A, Elliott A, Kelly P, Barfoot R, Chagtai T, Jayatilake H, Ahmed M, Spanova K, et al. 2006. Truncating mutations in the Fanconi anemia J gene BRIP1 are low-penetrance breast cancer susceptibility alleles. Nat Genet 38: 1239-1241. doi:10.1038/ng1902

Seo A, Steinberg-Shemer O, Unal S, Casadei S, Walsh T, Gumruk F, Shalev S, Shimamura A, Akarsu NA, Tamary $\mathrm{H}$, et al. 2018. Mechanism for survival of homozygous nonsense mutations in the tumor suppressor gene BRCA1. Proc Natl Acad Sci 115: 5241-5246. doi:10.1073/pnas.1801796115

Shaheen R, Faqeih E, Ansari S, Abdel-Salam G, Al-Hassnan ZN, Al-Shidi T, Alomar R, Sogaty S, Alkuraya FS. 2014. Genomic analysis of primordial dwarfism reveals novel disease genes. Genome Res 24: 291-299. doi:10.1101/gr.160572.113

Shimamura A, Alter BP. 2010. Pathophysiology and management of inherited bone marrow failure syndromes. Blood Rev 24: 101-122. doi:10.1016/j.blre.2010.03.002

Shimelis H, LaDuca H, Hu C, Hart SN, Na J, Thomas A, Akinhanmi M, Moore RM, Brauch H, Cox A, et al. 2018. Triple-negative breast cancer risk genes identified by multigene hereditary cancer panel testing. $J$ Natl Cancer Inst 110: 855-862. doi:10.1093/jnci/djy106

Steinberg-Shemer O, Goldberg TA, Yacobovich J, Levin C, Koren A, Revel-Vilk S, Ben-Ami T, Kuperman AA, Shkalim Zemer V, Toren A, et al. 2019. Characterization and genotype-phenotype correlation of patients with Fanconi anemia in a multi-ethnic population. Haematologica 105: 1825-1834. doi:10.3324/haematol 2019.222877

Tenenbaum-Rakover Y, Weinberg-Shukron A, Renbaum P, Lobel O, Eideh H, Gulsuner S, Dahary D, AbuRayyan A, Kanaan M, Levy-Lahad E, et al. 2015. Minichromosome maintenance complex component 8 (MCM8) gene mutations result in primary gonadal failure. J Med Genet 52: 391-399. doi:10.1136/jmedg enet-2014-102921

Wang K, Li M, Hakonarson H. 2010. ANNOVAR: functional annotation of genetic variants from high-throughput sequencing data. Nucleic Acids Res 38: e164. doi:10.1093/nar/gkq603

Weber-Lassalle N, Hauke J, Ramser J, Richters L, Groß E, Blümcke B, Gehrig A, Kahlert AK, Müller CR, Hackmann K, et al. 2018. BRIP1 loss-of-function mutations confer high risk for familial ovarian cancer, but not familial breast cancer. Breast Cancer Res 20: 7. doi:10.1186/s13058-018-0935-9

Weinberg-Shukron A, Rachmiel M, Renbaum P, Gulsuner S, Walsh T, Lobel O, Dreifuss A, Ben-Moshe A Zeligson S, Segel R, et al. 2018. Essential role of BRCA2 in ovarian development and function. N Engl J Med 379: 1042-1049. doi:10.1056/NEJMoa1800024

Wu Y, Sommers JA, Suhasini AN, Leonard T, Deakyne JS, Mazin AV, Shin-Ya K, Kitao H, Brosh RM Jr. 2010. Fanconi anemia group J mutation abolishes its DNA repair function by uncoupling DNA translocation from helicase activity or disruption of protein-DNA complexes. Blood 116: 3780-3791. doi:10.1182/ blood-2009-11-256016 


\section{COLD SPRING HARBOR Molecular Case Studies}

\section{Helicase-inactivating BRIP1 mutation yields Fanconi anemia with microcephaly and other congenital abnormalities}

Lara Kamal, Sarah B. Pierce, Christina Canavati, et al.

Cold Spring Harb Mol Case Stud 2020, 6: a005652

Access the most recent version at doi: $10.1101 /$ mcs.a005652
Supplementary http://molecularcasestudies.cshlp.org/content/suppl/2020/10/07/mcs.a005652.D Material C1
References This article cites 53 articles, 22 of which can be accessed free at: http://molecularcasestudies.cshlp.org/content/6/5/a005652.full.html\#ref-list-1
License This article is distributed under the terms of the Creative Commons Attribution-NonCommercial License, which permits reuse and redistribution, except for commercial purposes, provided that the original author and source are credited.
Email Alerting Receive free email alerts when new articles cite this article - sign up in the box at the Service top right corner of the article or click here.

